\title{
Rus Dilinde Etnonimler: Biçimsel ve Anlamsal Özellikler
}

\author{
Olena KOZAN*
}

\begin{abstract}
Öz
Soy, kavim, topluluk, ulus gibi oluşumları adlandıran etnonimler, adbilim çerçevesinde oluşan etnonimi dalının araştırma nesnesidir. Etnonimler gerek art zamanlı gerekse eş zamanlı olarak incelenebilmektedir. Etnonimlerin art zamanlı incelenmesi günümüze kadar gelen yazılı kaynakların çözümlemesi ile ilişkilendirilmektedir. Art zamanlı inceleme, etnonimin ne zaman ortaya çıktığı, etnonimin anlamının ne olduğu ve zamanla değişip değişmediği gibi sorular üzerinde durmaktadır. Etnonimlerin art zamanlı incelenmesinin tarih araştırmaları için son derece önemli olduğu anlaşılmaktadır. Eş zamanlı çözümleme çerçevesinde etnonimler dil dizgesindeki birimler olarak ele alınmakta ve dilsel süreçler açısından incelenmektedir. Ayrıca etnonimlerin biçimsel ve anlamsal özellikleri tespit edilmekte ve betimlenmektedir. Bu çalı̧̧mada çağdaş Rus dilindeki etnonimlerin eş zamanlı çözümlemesi yapılmış ve bu birimlerin biçimsel ve anlamsal özellikleri betimlenmiştir. Çağdaş Rus dilindeki etnonimlerin biçimsel özelliklere göre iki gruba ayrılabildiği gösterilmiştir. Ayrıca eylemci adlandırma modellerinde kullanılan son ekler yardımıyla türetilebilen etnonimler ve biçim birimleri kullanılmadan kök isimden türetilen etnonimler söz konusudur. Çağdaş Rusçada etnonimlerin çoğunun birinci grupta yer aldığ 1 , ancak tek bir modele göre türetilmediği tespit edilmiştir. İkinci gruptaki kök isimden türetilmiş etnonimlerin eskiden şekillenmiş etnik grupların adlandırması olduğu belirlenmiş̧tir. Rusçadaki etnonimlerin anlamsal çözümlemesi sonucunda bu birimlerin, kültürel bileşeni yoğun olan oluşumlar olduğu tespit edilmiştir. Rusçadaki etnonimlerin yan anlamlar kazandığı ve metafor olarak kullanılabildiği gösterilmiştir. Çağdaş Rusçadaki etnonimlerin en büyük özelliklerinden birinin ikincil adlandırma sürecinde kullanılması olduğu belirlenmiştir. Etnonimlerin eş zamanlı betimlenmesi sonucunda elde edilen verilerin yabancı dil ve çeviri eğitimi açısından önem taşıdığı ileri sürülmüştür. Bunun yanı sıra etnonimlerin art ve eş zamanlı çözümlemesinin, bir kültürde başka bir toplum ile ilgili imgelerin nasıl oluştuğu ve geliştiğine dair geniş bilgi sunabildiği ve bu birimlerin imgebilim çerçevesinde ele alınması gerektiği vurgulanmıştır.
\end{abstract}

Anahtar Kelimeler: Rusça, adbilim, etnonimler, yan anlam, ikincil adlandırma

\footnotetext{
* Öğr.Gör., Dr., Ankara Hacı Bayram Veli Üniversitesi, Edebiyat Fakültesi, Rus Dili ve Edebiyatı Bölümü, Ankara, Türkiye. Elmek: olena.kozan@gmail.com https://orcid.org/0000-0002-7956-4567
}

Geliş Tarihi / Received Date: 20.04.2019 Kabul Tarihi / Accepted Date: 01.09.2019 


\title{
Ethnonyms in the Russian Language: Formal and Semantic Features
}

\begin{abstract}
Ethnonyms, which are the names of such formations as a family group, a tribe or an ethnos, are the scientific object of the ethnonymics in the framework of onomastics. Ethnonyms can be studied in a diachronic and synchronic way. The diachronic study of the ethnonyms implies the analysis of the written sources from different periods. The diachronic study focuses on the origin of an ethnonym, its meaning and changes in the meaning over time. The results of the diachronic analysis are of special importance to history studies. The synchronic study deals with ethnonyms as units of the language system. The synchronic study aims at defining and describing the structural and semantic feautures of the ethnonyms. This article examines ethnonyms in the modern Russian language in a synchronic way and deals with the structural and semantic feautures of these units. The ethnonyms in the Russian language can be divided in two groups according to their formal features. These are ethnonyms derived with the suffixes used in the agent naming models and ethnonyms derived from the root words without morphemes. The study shows that most of the ethnonyms in the modern Russian language have derivational suffixes in their structure but there is no single derivation model. The ethnonyms based on the root words are seemed to be the names of the ethnic groups formed a long time ago. The semantic analysis of the ethnonyms illustrates that these units have strong cultural connotations and can be used as metaphors. The study shows that the ethnonyms in the modern Russian language are used in secondary naming. These features of the ethnonyms are underlined as important in the context of foreign language teaching and translation training. The diachronic and synchronic study of the ethnonyms is believed to highlight the process of image formation towards the foreigners. The importance of the study in the framework of the imagology is underlined.
\end{abstract}

Keywords: Russian language, onomastics, ethnonyms, connotation, secondary naming 


\section{Extended Summary}

Ethnonyms are understood as self-names of an ethnos and as names given to the ethnos by out-groups. Ethnonyms are dealt with in the framework of ethnonymics which is a research area in onomastics. This paper presents the description of formal and semantic characteristics of the ethnonyms in the modern Russian language.

The ethnonyms in the Russian language can be divided in two groups according to their formal feautures. These are ethnonyms derived with the suffixes used in the agent naming models and ethnonyms derived from the root words without morphemes. The study shows that most of the ethnonyms in the modern Russian have derivational suffixes in their structure but there is no single derivation model.

Ethnonyms in the modern Russian have both singular and plural forms. But the category of grammatical number in the ethnonyms was not the same in the Old Russian and changed over time. The ethnonyms in the Old Russian as it can be seen from the written sources were used in the plural. These ethnonyms were formed with the-ане, -ичи, -ята suffixes used in the group names according to different criteria such as the name of the founder, the place or the name of "the others". Some ethnonyms were formed with - bu u suffix which was rarely used in the Old Russian but got widespread use in the modern Russian and can be seen in the structure of the most ethnonyms.

The study shows that the singular in the ethnonyms appeared as the masculine singular. The most ethnonyms in the modern Russian have -eu suffix in the masculine singular form. The $-e u$ model is sometimes replaced by the $-u \mu$ model because of the phonetic laws in Russian. The feminine singular in the ethnonyms appeared over time and was formed with the multifunctional $-\kappa a$ suffix.

The ethnonyms derived from the root words without morphemes are shown to be the names of the ethnic groups which had shaped their self-definition by the time of first contacts with the Russians and their language. This 
"zero-morpheme" derivation model is totally replaced by the suffix model in the modern Russian.

The roots of the ethnonyms in the modern Russian coincide with the roots of the country names in most of the cases. But sometimes there are exceptions which can be explained by the non-linguistic factors.

The etnnonyms in the modern Russian can be a base for forming new words which belong to different word classes. As a result there are verbs, nouns, adjectives and adverbs derived from the ethnonyms. The most distinctive feature of these derivatives is their capacity to convey subjective evaluation of the speaker towards the situation.

The semantic analysis of the ethnonyms illustrates that these units have strong cultural connotations and can be used as metaphors. Some cultural connotations can imply pejorative evaluation of the ethnic group and form the basis for creating ethnic stereotypes and ethnic slurs.

The study shows that the ethnonyms in the modern Russian language are used in secondary naming. Some names of the plants and household items in Russian are secondary derivatives from the ethnonyms.

These features of the ethnonyms are underlined as important in the context of foreign language teaching and translation training. The diachronic and synchronic study of the ethnonyms is believed to highlight the process of image formation towards the foreigners. The importance of these studies in the framework of the imagology is underlined. 


\section{Giriş}

Etnonim bir soy, kavim, boy, topluluk, ulus gibi oluşumların adı olarak tanımlanmaktadır (Podolskaya, 1978, s. 167; Yartseva, 1998, s. 598). Kimi araştırmacılar bu tanımın içeriğini genişletip şehir, bölge sakinlerinin isimlerini de “etnonim" olarak adlandırmaktadır (Smirnov, 2012, s. 204). Etnonimler onomastik (adbilim) çerçevesinde oluşan etnonimi alanında incelenmektedir. Rusya'da etnonimi, bilim dalı olarak 1940'lı yıllarda şekillenmeye başlamıştır. O tarihten önce farklı ulusların, halkların isimlerinin kökeni ile ilgili birçok çalışmanın yapılmasına rağmen dilsel olgu olarak etnonimler A. Dementyev, V. Abayev, İ. Kovalik vb. araştırmacıların çalışmalarında o dönemde ele alınmaya başlanmıştır (Artzoyeva, Khalidov, 2017b, s. 203). 1960-70’li y1llarda etnonimler Rus araştırmacıların ilgi odağındaydı. Slav dillerindeki etnonimlerin yapısı ve türetme modellerinin yanı sıra genetik akrabalığı olmayan dillerdeki etnonimler de incelenmeye başlanmıştır (Nikonov, 1970). Ayrıca Türk dillerindeki etnonimlerin yapıs1 ve semantiği ile ilgili $K$ semantike turkskoy etnonimii (Türk Dillerindeki Etnonimlerin Semantiği Üzerine) başlıklı bir çalışma 1970 yılında V. Nikonov'un editörlüğündeki Etnonimi (Etnonimler) adlı kitapta yayımlanmışırı (Yeremeyev, 1970) ${ }^{1}$. Günümüzde Rusya'da etnonimi alanında etnonimlerin art zamanlı betimlemelerinin yanı sıra eş zamanlı betimlemeleri de yapılmaktadır. Ayrıca etnonimlerin biçimsel özellikleri (Ahmetova, 2013), etnonimlere yönelik sınıflandırmalar (Plis, 2018), etnonimlerin yan anlamları (Gritsenko, 2006), etnonim türevleri (Starovoytova, 2015; Kaliuşçenko, 2016), etnonimleri içeren deyimler ve metaforlar (Averçenko, 2018; Skorobogatova, 2006), etnofolizmler² (Smirnov, 2012; Grişçenko, Nikolina, 2006), etnik lakaplar (Dolya, 2016), etnonimlerin çevirisi (Tsebrovskaya, 2017) gibi konular incelenmektedir. Farklı dillerdeki etnonimlerin yan anlamları ve imgeleri açısından karşılaştırılması da araştırmacıların ilgisini

1 Rusya’da "Türk" etnonimi ile ilgili araştırmalar o tarihten önce başlamıştır (Kononov, 1949, s. 40).

2 Etnofolizm (Yunanca $\tilde{\varepsilon} \theta v o \varsigma$ (millet, budun) ve $\varphi \alpha \tilde{v} \lambda$ ৎৎ (kötü, berbat)) kavramı etnonimlerle ilgili araştırmalarda kullanılmakta ve anlatım gücü yüksek olan norm dışı etnonim olarak nitelenmektedir (Grişçenko, Nikolina, 2006, s. 176). 
çeken alanlardan biridir (Pantyuhova, 2013; Pitina, 2016; Znaçenok, Plis, 2018).

Türkiye'de etnonimi henüz üzerinde durulmamış bir alandır (Şahin, 2018, s. 1). Etnonimler daha çok ortaya çıkışı açısından art zamanlı olarak (Bayat, 2004; Hasanov, 2009) ya da belli bir eser çerçevesinde ele alınmaktadır (Nadirbayeva, 2016). Etnonimlerin eş zamanlı betimlenmesi araştırmacıları bekleyen bir alan olarak görünmektedir. Ayrıca etnonimlerin temelinde bulunduğu sözcük türetme ağlarının yapısı ve semantik özellikleri, etnonimler bazında türetilebilen benzetmeler ve metaforlar, etnonimlerin ikincil adlandırma aracı olarak kullanım1, etnonimlerin yan anlamları, farklı dillerdeki etnonimlerin karşılaştırılması gibi konular henüz araştırılmamış alanlar olarak karşımıza çıkmaktadır.

Bu çalışmada Rus dilindeki etnonimlerin eş zamanlı çözümlemesi yapılmıştır. Çalışmanın kapsamında çoğunlukla dış etnonim ${ }^{3}$ olarak nitelenen birimler üzerinde durulmuştur. Dış etnonimler, Rusçanın yabancı dil olarak öğretiminin ilk aşamalarındaki önemi ve verilerin dilbilimsel imgebilim çerçevesinde yapılabilecek karşılaştırmalı çalışmalarda kullanımı açısından seçilmiş̧ir. Çalışmada Rus dilindeki etnonimlerin yapısal ve anlamsal özellikleri betimlenmiştir. Rus dilindeki etnonimler dahil olduğu dilsel süreçler açısından incelenmiştir: Ayrıca Rus dilindeki etnonimlerin biçimsel özellikleri, etnonim türevleri, etnonimlerin yan anlamları, etnofolizmler, etnonimlerin ikincil adlandırmalarda kullanımı üzerinde durulmuştur.

\section{Biçimsel Özellikler}

Bir dildeki etnonimlerin biçimsel özelliklerinin incelenmesi bu dil dizgesindeki adlandırma modellerinin çözümlenmesine bağlıdır. Etnonim, dil dizgesi açısından bir eylemcidir. Böylece bir dildeki etnonimlerin, o dizgedeki eylemci adlandırma modellerini yansıtması beklenebilir. Bunun yanı sıra dildeki tüm etnonimlerin aynı modellere göre türetilmediği de varsayılabilir. Etnonimlerin ortaya çıkışını sağlayan dil dışı etkenler değişken olduğu için etnonimlerin dilsel biçimleri de farklılık gösterebilmektedir". Çağdaş Rus dilindeki etnonimler biçimsel

\footnotetext{
3 Dıș etnonim "bir ulusun/topluluğun dilindeki başka uluslara/topluluklara yönelik kullanılan adlandırmalar" olarak nitelenebilir. Rusya'da geliştirilen etnonimi alanında alloetnonim (ya da ekzogenniy etnonim) (başka uluslar tarafından verilen ad(lar), avtoetnonim (ya da endogenniy etnonim) (ulusun kendine verdiği ad(lar) gibi terimler kullanılmaktadır (Podolskaya, 1978, s. 168).

4 Etnonimlerin adlandırılmasındaki etkenlerin sınıflandırılması ile ilgili bkz. (Nikonov, 1970).
} 
özelliklere göre iki gruba ayrılabilir: Eylemci adlandırma modelini yansıtan son ekli türevler ve son ek kullanılmadan türetilen birimler. Çağdaş Rusçadaki etnonimlerin çoğu birinci grupta yer almaktadır.

\section{Biçim Birimlerinin Kullanımı: Son Ekler}

Rus dili dizgesindeki etnonimlerin türetiminde kullanılan son eklerin sayıs1 50'den fazladır (Gorodetskaya, Levaşov, 2003, s. 4). Ancak çağdaş Rusçada bazı son ekler verimli adlandırma modelleri oluşturduğu için yaygın olarak kullanılırken, diğerleri nesilden nesile aktarılan kalıplaşmış etnonimlerde görülebilir. $\mathrm{Bu}$ durum özellikle iç etnonim olarak nitelediğimiz Rusya'nın bulunduğu topraklarda yaşayan milletler, topluluklar, bölge ve şehir sakinlerinin adlandırmalarında gözlemlenebilir.

Diğer Slav dillerinde de olduğu gibi Rusçadaki ilk etnonimler boy ya da kavmin adı biçiminde olup çoğul şekilde türetilmiştir. Böylece etnonimlerin tekil biçimleri ikincil bir türev olarak kabul edilmektedir (Kovalev, 1991, s. 40; Gorodetskaya, Levaşov, 2003, s. 7). Slav dillerindeki etnonimlerin adlandırmasında tespit edilen ortak son ekler -ане, -ичи, -яmа ${ }^{6}$ biçimindeydi (Kovalev, 1991, s. 40; Nikonov, 1970, s. 25). Bu son eklerin kullanımının belli bir modele dayandığ anlaşılmaktadır. Ayrıca -ичи, -ята son ekleri ataların ismine eklenip boyun adında kullanılmaktaydı (радимичи (Radim oğulları)) ${ }^{7}$. -ане son eki ise yer adları bazında boy ya da kavmin adının türetilmesinde kullanılmaktaydı. Örneğin, славяне (Slavlar) etnoniminin ortaya çıkışını açıklayan yaklaşımlardan birine göre Slavlar, Slavuta nehrinin kenarında yaşayan insanlardır (Nikonov, 1970, s. 25). -ане son eki sadece Slav topluluklarının değil, "öteki” toplulukların adlandırılmasında da kullanılmaktaydı: агняне (англичане) (İngilizler), римляне (Romalılar), египтяне (Misırlılar), израильтяне (İsrailliler), филистиняне (Filistinliler) vs. (Kovalev, 1991, s. 49). Bu son eklerin yanı sira -j- son eki ile türetilen ${ }^{8}$ topluluk

5 Bu özellik diğer Slav dillerinde de gözlemlenebilir (Gorodetskaya, Levaşov, 2003, s. 4).

6 Çağdaş Rusçada bu son ek "yavru” paradigmasında görülebilir: утята (ördek yavruları), цыплята (civcivler) vs. İnsan ile ilgili девчата (kızlar), ребята (çocuklar; hitap biçimi olarak "arkadaşlar”) gibi türevler de mevcut.

7 Ancak bu son ekin işlevi, antroponim bazında kavim adlarının türetilmesi ile sınırlı değildir. Örneğin yer adlarından türetilen etnonimlerde de bu son ek görülebilir: Москва $\rightarrow$ москвичи (Moskova- Moskovalılar). Bunun yanı sıra дрегва $\rightarrow$ дреговичи (bataklık-bataklık bölgesinde yaşayanlar); люди лютые $\rightarrow$ лютичи (sert insanlar-sert insanlardan gelenler) vs. farklı türevler de mevcuttur.

8 Eski Rusçada йотовый суффикс (“yot” sesi bazında türetilen son ek) olarak bilinmekte, çağdaş Rusçada ise sözcüğün sonundaki $-b$ harfi ile aktarılmaktadır. 
isimleri de mevcuttu: чудь (Çud), самоядь (Samoyed), ямь (Yam), корсь (Kors), русь (Rus) ${ }^{9}$. Araştırmacılara göre bu son ek daha çok Fin-Ugor halklarının adlandırılmasında kullanılmakta olup yaygın bir modelin ortaya çıkmasını sağlamamıştır (Nikonov, 1970, s. 28). Slav dillerindeki etnonimlerin türetilmesinde kullanılan ortak -ане, -ичи, -ята son eklerinin dışında Eski Rusçada bazı etnonimler -ьци son eki ile türetilmiştir (дунайцы (Tuna nehri bölgesinde yaşayanlar), немцы ${ }^{10}$ (Almanlar), половцы (Kıpçaklar) (Kovalev, 1991, s. 53). Araştırmacılar, bu son ekin etnonimlerin türetilmesinde nadir kullanıldığını ancak zamanla aktif hale geldiğini ileri sürmektedir. Ayrıca çağdaş Rusçada eylemcinin adlandırılmasında kullanılan bu son ek modeli ${ }^{11}$, etnonimlerin türetilmesinde en çok kullanılan model olarak kabul edilmektedir (Nikonov, 1970, s. 26; Kovalev, 1991, s. 55; Gorodetskaya, Levaşov, 2003, s. 7).

Çağdaş Rusçada etnonimlerin biçimsel özellikleri önceki dönemlere göre farkl1lık göstermektedir. İlk önce çağdaş Rusçadaki etnonimlerin "bilişsel yapısı"nın değiştiğini söylemek gerekir. Çağdaş Rusçada etnonimlerin çoğul kategorisinin yanı sira tekil kategorisi de mevcuttur. Tekil paradigmasında eril ve dişil adlandırmalar kullanılmaktadır. Örneğin, Европа-европеец-европейка ${ }^{12}$ (Avrupa-Avrupalı (erkek)-Avrupalı (kadın)). Bunun yanı sıra çağdaş Rusçadaki etnonimlerin türetiminde kullanılan son eklerin dağılımı da farklıdır. Bu durumda etnonimlerin çoğul kategorisini ve eril ile dişil biçimlerini bulunduran tekil kategorisini tek tek betimlemek gerekmektedir.

Çağdaş Rusçada tekil eril biçimindeki etnonimlerin çoğu dil dizgesindeki eylemciyi adlandıran $-e$ s son eki ${ }^{13}$ ile türetilmiştir. Rusçada $-e u$ son eki olan türevler meslek (петь-певец (şarkı söylemek-şarkı1)), eylemcinin özelliği (юныйюнец (genç (sıfat)-genç (isim)), молодой-молодец (genç (sıfat)-genç (isim, eski

\footnotetext{
9 Русь, русины, русичи, русские (Ruslar) etnonimlerinin ortaya çıkışı günümüzde de tartışılan bir konudur (Kovalev, 1991, s. 46).

10 Çağdaş Rusçada немец etnonimi Almanlar için kullanılmaktadır. Ancak sözcüğün düz anlamı "немой” (dilsiz) olduğu için Eski Rusçada Rusçayı konuşamayan yabancılara yönelik kullanılmaktaydı (Popova, Al-Hamdani, 2018, s. 97).

$11 \mathrm{Bu}$ son ekin Eski Rusçada bile çoğul-tekil paradigması mevcuttu: ци-ец (певцы-певец (şarkıcılar-şarkıcı)) (Kovalev, 1991, s. 55).

12 Çağdaş Rusçada etnonimler küçük harf kuralına göre yazılmaktadır. Bunun sebebi etnonimlerin daha çok cins isim kategorisine kayma eğilimidir. Etnonimlerin özel ya da cins isim kategorisine ait olup olmadığı ile ilgili tartışmalar günümüzde de devam etmektedir (Nikonov, 1970, s. 5).

13 Rusçadaki -eu son eki sonuç ya da süreç odaklı olguların adlandırılmasında da kullanılmaktadır. Bu durumda fiilden isim yapma biçimindeki adlaştırma işlevinden söz edilebilir. Örneğin, кончать-конец (son vermek/sonlandırmak-son); рубать-рубец (vurarak kesmek-yara izi).
} 
kullanım) $\rightarrow$ aferin sana (övme biçimi)), belli bir eylemde bulunmuş kişi ${ }^{14}$ (лгатьлжец (yalan söylemek-yalan söylemiş biri)) gibi kategorilerin adlandırılmasında kullanılmaktadır. Böylece Rusçadaki etnonimin adlandırılmasında dil dizgesinde belli bir özelliği olan eylemci adlandırma modelinden faydalanıldığı görülür. Örneğin итальянец (İtalyan), испанец (İspanyol), палестинец (Filistinli), голландец (Hollandalı), австриец (Avusturyal1), эстонец (Estonyalı), албанец (Arnavut), дагестанец (Dağıstanlı), чеченец (Çeçen), китаец (Çinli), японец (Japon), мексиканец (Meksikalı) vs. Bu modelin, belli bir etnik gruba ait kişinin adlandırılmasının yanı sıra farklı milletlerin yaşadığı ülke sakininin adlandırılmasında kullanıldığ1 görülür. Örneğin Бельгия-бельгиец (Belçika-Belçikalı), Люксембурглюксембуржец (Lüksemburg-Lüksemburglu), Пакистан-пакистанец (PakistanPakistanl1), Бангладеш-бангладешец (Bangladeş-Bangladeşli). Bu gruptaki etnonimlerin üst gruptakilerden farklı olarak ülke adından türetildiği anlaşılmaktadır. Başka bir deyişle tarih sahnesine ilk çıkan siyasi bir oluşum olmuş, bu siyasi oluşumun sınırları somutlaştıkça o sınırlar içinde yaşayan halkların adı ülke adından türetilmiştir. Örneğin bu modele göre Украина-украинец (Ukrayna-Ukraynalı) biçimi de oluşmuştur. Ayrıca 20. yüzyıla kadar bugünkü Ukrayna’nın bulunduğu topraklarda yaşayan Slav kökenli halk малороссы (Küçük Ruslar), bu topraklar ise Малая Русь, Малороссия (Küçük Rusya) olarak adlandırılmıştır. Ancak bu adlandırmadaki малый (küçük) sözcüğ̈̈ “ilk ortaya çıkan”, "Rusların çıkış noktası” olan anlamı taşıyordu. Bugünkü Rusya Federasyonu ise Великороссия (Вüyük Rusya) olarak biliniyor ve Küçük Rusya'nın genişletilmiş toprakları olarak düşünülüyordu ${ }^{15}$ (Savitski, 2009, s. 5). Украина sözcüğ̈̈ ise (y/o (yanında, yakında anlamındaki edat); край/краина (sınır, kenar, hudut)) yazılı kaynaklarda "sınırda, kenarda bulunan topraklar" anlamında kullanılıyordu (Subtelnı, 1993, s. 5; Gruşevski, 1992, s. 2). 20. yüzyılın başlarında cins isim olan украина siyasi bir oluşum haline gelmiş ve Украина biçiminde özel isim niteliğini kazanmıştır. Bu ülkenin adından hareketle de украинцы-украинец-украинка (Ukrayna-Ukraynalı (erkek)Ukraynalı (kadın)) türevleri ortaya çıkmıştır (Nikonov, 1970, s. 22).

14 Rusçada eylemcinin adlandırılmasında bir eylemde bir kere bulunması ya da eylemi sürekli yapması gibi kriter kendisini gösterebilmektedir (Krasilnikova, 2001, s. 30). Örneğin, лгать-лжец-лгун (yalan söylemek-belli bir durumda yalan söylemiş biri-yalancı (eylemcinin özelliği olarak düşünülmektedir)).

15 Benzer bir durum "İngiltere-Büyük Britanya" kavramlarında görülebilir: merkez-merkeze bağlanan topraklar olarak ilișkilendirilmektedir. 
Yukarıda verilen örneklerde Rusça millet ya da ülke sakinlerinin adlarının, yaşadıkları ülke adlarıyla biçimsel olarak örtüştügü görülür. Çok nadir durumlarda etnonim ve ülke adı farklılık göstermektedir. Etnonim adının ülke adıyla örtüşmemesi dil dışı etkenlerle ilişkilendirilebilir. Örneğin Slavların Germenlerle ilişkiler kurması çok eski zamanlara dayanmaktadır. Temaslar başladığında Germenler, Slav dillerini konuşamayan diğer kavimler gibi Slavlar tarafından "dilsiz", "dili konuşamayan" anlamındaki немец olarak adlandırılmıştır. Böylece немец adlandırmasının ilk başta her yabancı için kullanıldığı anlaşılmaktadır (Popova, Al-Hamdani, 2018, s. 97). Ancak zamanla bu adlandırmanın anlamsal alanı daralmış ve немец, "Batı Avrupalı; Germen dilleri konuşan halklardan biri” olarak algılanmaya başlamıştır. Bunun yanında 19. yüzyıl Rusçasında немец etnoniminden "yurt dışı", "Batı Avrupa", "Germenlerin yaşadıkları yer" anlamındaki Неметчина türevi da mevcuttu (Popova, Al-Hamdani, 2018, s. 104). 20. yüzyılda ortaya çıkan yeni bir siyasi oluşum Rusçaya Германия (Germenlerin ülkesi, Almanya) adıyla girmiş, ancak halkı adlandıran eski etnonim geleneksel olarak kullanılmaya devam etmiştir. Böylece Германия- немец-немка-немцы (Almanya-Alman (erkek)-Alman (kadın)-Almanlar) türevlerinde biçimsel örtüşmezlik ortaya çıkmıştır.

Yukarıda dile getirildiği gibi çağdaş Rusçadaki -eu son eki etnonimlerin adlandırılmasında kullanılan en yaygın biçim birimidir. Bu son ekin kıta, bölge ve yeni siyasi oluşumlar ile ilişkilendirilen türevlerde kullanıldığı görülebilir. Örneğin "kıta-sakin" paradigması Европа-европеец (Avrupa-Avrupal1), Африкаафриканец (Afrika-Afrikalı), Америка-американец (Amerika-Amerikal1), Австралия-австралиец (Avustralya-Avustralyal1) biçimindedir" ${ }^{16}$."Bölge-sakin" paradigması Кавказ-кавказец (Kafkasya-Kafkasyal1), Урал-уралец (Ural-Ural1) örneklerinde görülebiliri ${ }^{17}$.

Çağdaş Rusçada son eklerin kaynaşması da görülebilir. Ayrıca -eu son ekinin -ob/-uH/-aн son ekleriyle kaynaştığı durumlar söz konusudur (Nikonov, 1970, s. 26). Örneğin Америка-американец (Amerika-Amerikal1), Баку-

16 Asya-Asyalı paradigması Азия-азиат biçimindedir. Bu durumda - ия bükümü ile biten birimin -am son ekini gerektirdiği görülebilir.

17 Bazı durumlarda bölge-sakin paradigmasında $-я \kappa$ son eki görülebilir: Сибирь-сибиряк (Sibirya-Sibiryalı), Пермьпермяк (Perm-Permli), земля-земляк (toprak-hemşehri, memleketli). Çoğu zaman bu son ek güney ve doğuda yaşayan halkların adlandırılmasında kullanılmıştır (Nikonov, 1970, s. 26). 
бакинец (Bakü-Bakülü), Куба-кубинец (Küba-Kübalı), Ялта-ялтинец (YaltaYaltal1).

Çağdaş Rusçada -eu son eki ile türetilen eril tekil biçim -u̧b biçimindeki çoğul ile ilişkilendirilmektedir: Аyrıca македонец-македонцы (Makedonya11-Makedonyal1lar), индонезиец-индонезийцы (Endonezyal1-Endonezyal1lar), филиппинец-филиппинцы (Filippinli-Filippinliler) vb. türevler söz konusudur.

Rusçadaki etnonimlerin tekil paradigması içinde dişil kategorinin bulunması, dilbilgisel cinsiyet kategorisine sahip olan bir dil dizgesi açısından son derece doğal ve mantıklı görünmektedir. Ancak Rusçanın dizgesinde var olan dişil kategorisi uzun süre boyunca etnonimlerin yapısında kendisini göstermemiştir ${ }^{18}$ (Gorodetskaya, Levaşov, 2003, s. 9). Bu durum bir taraftan kadının toplumdaki statüsü ile açıklanabilir. Diğer taraftan ise eski zamanlardan beri kadının adlandırılmasının, ikamet ettiği yere ya da ait olduğu etnik gruba göre değil baba, koca ya da onların mesleklerinin adlarına göre yapıldığı bilinmektedir (мельникмельничиха (değirmenci-değirmencinin kızı/karıs1), Макар-Макариха (MakarMakar'ın kızı/karısı) (Kovalev, 1991, s. 104). Çağdaş Rusçada etnonimlerin dişil biçiminin türetim sürecinde oluşabilen zorluklar daha çok yapısal boyuttadır. Rusçada dişil kategorisinin türetilebildiği en yaygın biçimlerden biri $-\kappa a(-x a)$ son ekidir. Ancak bu son ek, sözcüğün gövdesinin sonundaki bazı ünsüzler kombinasyonu ile yan yana geldiğinde dil dizgesindeki ses yasaları dişil biçiminin ortaya çıkmasını engellemektedir. Örneğin bu durum $-\kappa,-x,-u,-\iota$ ile biten (Ирак (Irak), Бангкок (Bangkok), Котельнич (Kotelniç)), sözcüğün içinde birkaç ünsüzün yan yana bulunduğu (Кяхта (Kyahta)) yer isimlerinde ve birtakım diğer kombinasyonlarda görülebilir (Goroddetskaya, Levaşov, 2003, s. 9).

Çağdaş Rusçada - eu son eki ile türetilen eril tekil biçim $-\kappa a$ biçimindeki dişil tekil ile ilişkilendirilmektedir. Örneğin албанец-албанка (Arnavut (erkek)-Arnavut (kadın)), эстонец-эстонка (Estonyalı (erkek)-Estonyalı (kadin)), кореец-кореянка (Koreli (erkek)-Koreli (kadın)).

Çağdaş Rusçada etnonimlerin adlandırılmasında kullanılan -eu son ekinin yanı sıra $-и н$ son eki ya da bu son ekin -aнин gibi kaynaşmış biçimleri de sıkça

18 Örneğin Rusça en eski yazılı kaynaklardan biri olan Povest Vremennıh Let (Nestor Kroniği) adlı vakayinamede sadece üç etnonimin dişil biçimi görülebilir. Bunlar dönemin knezlerinin eşlerinin adlandırılmasıdır: Грекиня (Grek), Болгарыня (Bulgar) и Чехиня (Çek) (Kovalev, 1991, s. 104). 
görülebilir. Örneğin татарин (Tatar), болгарин (Bulgar), грузин (Gürcü), армянин (Ermeni), англичанин (İngiliz), датчанин (Danimarkalı), египтянин (Misırlı), израильтянин (İsrailli), минчанин (Minskli). Bu son ek gerek Rusçada gerekse diğer Slav dillerinde eski dönemlerde sıkça kullanılırken günümüzde işlevselliğini kaybetmiş ve nadir durumlarda ses yasalarından dolayı yeni türevler vermektedir (Nikonov, 1970, s. 26; Kovalev, 1991, s. 48; Gorodetskaya, Levaşov, 2003, s. 8). Örneğin -чанин son eki, - -ск biçim birimi olan toponimlerden türetilen etnonimlerde görülebilir. Ayrıca bu durumda etnonimin isim kategorisindeki yer adından değil, ilgi sıfatından ${ }^{19}$ türetildiği de görülebilir: Горький-горьковский-горьковчанин (Gorki (şehir)-Gorki (sıfat)-Gorkili (isim)), Ростов-ростовский-ростовчанин (Rostov (şehir)-Rostov (sıfat)-Rostovlu (isim)) (Nikonov, 1970, s. 26). Bu noktada çağdaş Rusçadaki son ekler arasındaki "rekabet”"ten de söz edilebilir: eskiden -анин son ekinin kullanıldığı adlandırmalara - eu son eki yerleşmeye başlamıştır. Örneğin Ростов-ростовчанин-ростовец (Rostov-Rostovlu-Rostovlu), Орёл-орловчанинорловец (Orel-Orelli-Orelli) (Gorodetskaya, Levaşov, 2003, s. 8).

-анин/-янин son eki coğrafi bölgelerden türetilen sakinlerin adlandırılmasında görülebilir: север-северянин (kuzey- Kuzeyli), юг-южанин (güneyGüneyli). Bu noktada Rusçadaki yönler bazında türetilen kavramların özelliği ortaya çıkmaktadır. Kuzey ve güney bölgelerde yaşayanların adlandııılmış olduğu, ancak Batı'da ve Doğu'da yaşayanlar için genelleyen adlandırmaların oluşmadığı anlaşılmaktadır. Çağdaş Rusçada восток (Doğu) ve запад (Batı) bazında türetilen eylemci adlandırmalar farklı anlam içermektedir. Ayrıca çağdaş Rusçada восточник "yüksek eğitim kurumlarının Doğu Dilleri bölümünde okuyan öğrenci” anlamına gelmektedir (Buyakov, 1994). Bunun yanı sıra восточник "Rusya'nın Doğu'nun bir parçası olduğunu savunan bir yaklaşım taraftarı" olarak da kullanılmaktadır (Şulga, 2014, s. 88). Западник ise "19.yüzyılın Rus düşünce tarihinde Rusya'nın Batı'nın bir parçası olduğunu ve Batı'nın ilerlediği bir yoldan gelişmesi gerektiğini savunan bir yaklaşım taraftarı" olarak bilinmektedir ${ }^{20}$

$19-c \kappa /-u \kappa$ biçim birimi isim kategorisindeki yer adından yer ile ilgili niteliği dile getiren sıfat kategorisinin türetilmesinde kullanılmaktadır: Москва-московский (Moskova-Moskova (sıfat)), Англия-английский (İngiltere- İngiliz (sıfat)), Турция-турецкий (Türkiye-Türk (sıfat)).

20 Kanımızca Doğu ve Batı'da yaşayanlar için genel adlandırmaların olmaması Rusların devletleşme süreci ile ilişkilendirilebilir. Rusların ilk devleti olan Kiev Rusyası, Slavların yaşadıkları bölgeye göre güneyde bulunmaktaydı. 14.yüzyılda tarih sahnesine çıkan Moskova Knezliği ise kuzeydeydi. Kuzeyde ve güneyde yaşayan Slav halklarının konuştukları dillerde sessel değişikliklerin oluşmasının yanı sıra dil dışı etkenlerin de yol açtığı farklılıklar dolayısıyla "kuzeyli" ve "güneyli" kavramları oluşmuş ve dilde biçimlerini bulmuştur. 
(Diyanov, 2011, s. 82). Böylece çağdaş Rusçada "Batıll”" ya da "Doğulu” kavramları ancak açılamalı bir biçimde dile getirilebilir. Örneğin уроженец Востока (Doğu'da doğmuş biri), житель западных районов (Batı'daki bölgelerin sakini).

Çağdaş Rusçadaki $-u н$ son ekinin işlevselliğinin korunduğu alanlardan biri de din mensuplarının adlandırılmasıdır (мусульманин (Müslüman), христианин (Hristiyan)). Hinduizm, Budizm, Daosizm, Şintoizm daha çok felsefe, yaşam tarzı olarak düşünüldüğü için bu dini inançların mensuplarının adlandırılmasında -ucm son ekinin kullanıldığı görülebilir: индуист (Hindu), буддист (Buddist), даосист (Daosist), синтоист (Şintoist). Musevilik için çağdaş Rusçada iki biçim kullanılabilmektedir: иудаизм (Musevilik) vе иудейство (Musevilik). Bu iki biçimin adlandırılmasında Иуда (Yehud) özel isminin kullanıldığı görülür. Bu özel isimden hareketle иудей (Musevi) biçimindeki türev ortaya çıkmıştır.

Çağdaş Rusçada -(чан)ин son eki ile türetilen eril tekil biçim -(ч)a(я) не biçimindeki çoğul ile ilişkilendirilmektedir. Ayrıca египтянин-египтяне (Misırl1-Misırl1lar), англичанин-англичане (İngiliz-İngilizler), мусульманинмусульмане (Müslüman-Müslümanlar).

Tekil eril biçimi türeten - $-и н$ son eki ile ilişkilendirilen dişil biçim, $-\kappa a$ son eki ile türetilmektedir (англичанин-англичанка (İngiliz (erkek)-İngiliz (kadın), датчанин-датчанка (Danimarkalı (erkek)- Danimarkalı (kadın), христианинхристианка (Hristiyan (erkek)- Hristiyan (kadın)).

\section{Sıfır Biçim Biriminin Kullanımı}

Çağdaş Rusçada bazı etnonimler eylemci adlandıran son ekler olmadan türetilmiştir. Bu durum Rusçada ilk ortaya çıkan tekil eril ve çoğul paradigmasında görülebilir. Örneğin француз- французы ${ }^{21}$ (Fransız-Fransızlar), венгр-венгры (Маcar-Macarlar), финн-финны (Fin-Finler), швед-шведы (İsveçli-İsveçliler), грекгреки (Grek-Grekler), чех-чехи (Çek-Çekler), хорват-хорваты (Hırvat-Hırvatlar), серб-сербы (Sirp-Sirplar), румын-румыны (Romanyal1-Romanyalılar), латышлатыши (Letonyal1-Letonyal1lar), белорус-белоруссы (Beyaz Rus-Beyaz Ruslar), казах-казахи (Kazak-Kazaklar), узбек-узбеки (Özbek-Özbekler), туркмен-

21 M. Vasmer'e göre bu sözcük Alman lehçelerinden (Franzos) Rusçaya ödünçleme olarak girmiş ve Rusça açısından kök bir sözcük olarak kabul edilmektedir (1987, s. 206). 
туркмены (Türkmen-Türkmenler), таджик-таджики (Tacik-Tacikler), араб-арабы (Arap-Araplar). Bu türevlerin eskiden şekillenmiş etnik grupların adlandırılmasında ortaya çıktığı anlaşılmaktadır. Günümüzde sıfir biçim birimi modeli olarak düşünülebilen bu adlandırma modeli yeni ortaya çıkan oluşumlara yönelik kullanılmamak$\operatorname{tad}^{22}$. Stfir biçim birimi modeline göre oluşmuş etnonimlerin dişil tekil biçimi genel -кa son eki kuralına göre türetilmektedir. Örneğin венгр-венгерка (Macar (erkek)Macar (kadın)), швед-шведка (İsveçli (erkek)-İsveçli (kadın)), узбек-узбечка (Özbek (erkek)-Özbek (kadın)), араб-арабка (Arap (erkek)-Arap(kadın)). Nadir durumlarda bu modeldeki dişil türevlerde kaynaşmış -енка/-анка son ekleri görülebilir. Örneğin француженка (Fransız (kadın)), гречанка (Grek (kadın)).

\section{Etnonimlerin Dilbilgisel Sınıfı}

Yukarıdaki örneklerde görüldüğü gibi çağdaş Rusçadaki etnonimlerin özelliği, isim sınıfına ait olmasıdır. Bu paradigmanın tek bir istisnası olarak görünen русские-русский-русская (Ruslar-Rus (erkek)-Rus (kadın)) etnonimidir. Çağdaş Rusçada bu etnonim isim (adlaştırılmış sıfat) kategorisinde olsa da bunun biçimsel özellikleri, bu etnonimin nitelik aktaran sıfat bazında türetildiğini göstermektedir. Bu noktada Rusların ayrı bir halk olarak ortaya çıkması ve böylece ayrı bir etnonimin şekillenmesi ile ilgili günümüzde de tartışmaların yapıldığını ve araştırmacılar arasında ortak bir görüş olmadığını vurgulamak gerekir (Şahmatov, 1940, s. 11; Acar, 2014, s.20). Русский etnoniminin yapısındaki isimden sıfat yapan $-c \kappa$ son ekinin işlevi "bir nesne/olgu ile ilgili olan, ait olan bir şey" biçiminde açıklanabilir. Bu anlamda русский, "Rus" olarak adlandırılan bir yapıya ait ya da bu yapı ile ilişkili bir birim biçiminde düşünülebilir. Günümüze kadar ulaşan yazılı kaynaklardan yola çıkarak "Rus" sözcüğünün kullanıldığı bağlamlardan birinin, bugünlerde Kiev'in bulunduğu topraklar olduğu, diğerinin ise farklı kavimleri birleştiren bir oluşum olduğu anlaşılmaktadır (Mısenko, 2005, s. 54). $\mathrm{Bu}$ bağlamda русские etnoniminin, bugünlerde bir milletin adlandırılmasında kullanılsa da tek bir etnik grubun ya da kavmin adlandırılması olarak ortaya çıkmadığ 1 tahmin edilebilir. Ayrıca $-c \kappa$ son ekinin kullanımı da bu açıdan mantıklı

$22 \mathrm{Bu}$ durumda yukarıda da dile getirildiği gibi Rusça farklı son eklere başvurmaktadır. Kişi adı, yer adı gibi kriterler son eklerin tercihini yönlendirmektedir. Örneğin siyasi haritada Saudi Arabistan adlı bir ülke ortaya çıktığında Suudi-Suudiler biçiminde adlandırma da kullanılmaya başlamıştır. Ülkenin adında kurucusunun soyadı kullanıldığı için Rusçada -um son ekine başvurulmuştur: саудиты-саудит (Suudiler-Suudi). 


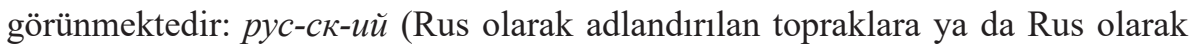
bilinen siyasi oluşuma ait olan biri).

Günümüzde русский etnonimi Rus halkından biri olarak algılanmaktadır. Farklı milletleri ve halkları birleştiren Rusya'da yaşayan Rusya vatandaşları için ülke adından türetilen biçimler kullanılmaktadır. Ayrıca Россия- россиянинроссиянка (Rusya-Rusyalı (erkek)-Rusyalı (kadın) türevleri söz konusudur. Bu model farklı milletleri barındıran ülkeler durumunda ortaya çıkmaktadır: Böylece Узбекистан- узбеки-узбекистанцы (Özbekistan-Özbekler-Özbekistanlılar), Казахстан-казахи-казахстанцьь (Kazakistan-Kazaklar-Kazakistanlılar).

Yukarıdaki örneklerden yola çıkarak çağdaş Rusçadaki aynı kök sözcükten türetilen etnonimlerin eş anlamlı birimler olmadığı anlaşılmaktadır. Bu bağlamda çağdaş Rusçadaki турки-тюрки etnoniminin özelliklerini de dile getirmek gerekmektedir. Турки-турок-турчанка (Türkiye Türkleri-Türkiye Türkü (erkek)Türkiye Türkü (kadın)) etnonimi Türkiye'de yaşayan Türkler için kullanılırken тюрки (Türk dünyasından olanlar) etnonimi Türk dünyası ile ilişkilendirilmektedir.

\section{Etnonim Türevleri}

Çağdaş Rusçadaki etnonimlerin özelliklerinden biri etnonim bazında farklı dilbilgisel kategorilere ait sözcüklerin türetilebilmesidir. Ayrıca Rusçada etnonim bazlı fiil türevleri' ${ }^{23}$, isim türevleri, sıfat ve zarf türevleri mevcuttur ${ }^{24}$. Etnonim bazlı sözcüksel türevlerin en büyük özelliği ise bu birimlerin öznel değerlendirmeleri bulundurabilmesidir. Başka bir deyişle bu türevlerin yapısında dile getirilen nesne ya da olguya yönelik konuşmacının tutumu ile ilgili bilgiler kodlanabilmektedir. Çağdaş Rusçada bu durum sözcüksel birimlerin duygu yoğunluğ ${ }^{25}$ araştırmaları çerçevesinde ele alınmaktadır (Yegorova, 2013, s. 44).

Rusçada etnonim bazında ön ve son eklerin yardımıyla etnonimin "şekillendirdiği”" eylemi dile getiren fiil türetilebilmektedir. Fiil, etnonimin tekil eril biçiminden son ek ya da ön ek kullanılmadan da türetilmektedir. Ayrıca etnonim bazında bu fiil türetme biçimi ilk olarak ortaya çıkan bir model olarak düşünül-

23 Rusçası деэтнонимические глагольные дериваты (Kaliuşçenko, 2016, s. 64).

24 Rusçada etnonim bazında türetilebilen sözcükler этнонимическая лексика (etnonim bazlı sözcüksel türevler) olarak nitelenmektedir (Gritsenko, 2006, s. 94)

25 Rusçası эмотивность. 
mektedir (Starovoytova, 2015, s. 155). Örneğin, француз-французить (Fransız"Fransız" bazında farklı anlamları içeren fiil biçimi), цыган-цыганить (Çingene"Çingene" bazında farklı anlamları içeren fiil biçimi). Rusçada bu fiiller, zamanla kazandığı farklı anlamlar açısından ilgi çekicidir. 18-19. yüzyıllarda bu fiillerin anlamsal alanında eylemci-nesne ilişkilerinin yapılandırılmasının olduğu kaydedilmiştir. Başka bir deyişle yazılı kaynaklarda bu birimler geçişli fiil olarak kullanılmıştır. Örneğin русить иностранные слова (уabancı sözcükleri Rusçanın yazma/okuma kurallarına göre yazmak/telaffuz etmek), французить русские фамилии (Rus soyadlarını Fransızcanın kurallarına göre telaffuz etmek) gibi öbeklerde kullanılan fiillerin anlamı "yabancı dil dizgesine uyarlamak" olarak açıklanabilir. Etnonim bazında oluşan fiilin anlamsal yapısında "bir eylemcinin nesne veya olguya uyguladığı eylem sonucunda bu nesne veya olgunun başka bir nesne ya da olguya dönüştürülmesi" biçiminde yorumlanabilen bir boyut görülebilir. Rusçanın dizgesine bu "dönüşüm" o-/oб(o)- ön ekleriyle kodlanabilmektedir (Russkaya Grammatika, 1980, s. 361). Dil dizgesindeki ön ekli modelin zamanla etnonim bazlı fiilleri de etkilediği anlaşılmaktadır. Aуrıca отурчить костюм (kendi kıyafetini Türklerin giydikleri kıyafete benzetmek, uydurmak; Türkler gibi giyinmek), оболгарить фамилию (soyadını Bulgarların soyadı modeline uydurmak), орусачить текст (metni Rusçaya çevirip Rus kültürüne uyarlamak) gibi kullanımlar söz konusudur (Starovoytova, 2015:156). O-/об(o)- ön eklerinin yanı sıra aynı anlamı aktarmak için sonuç odaklılığını içeren по- ön eki ve bir noktadan başka bir noktaya geçişi aktaran перe- ön ekinin (Russkaya Grammatika, 1980:363) kullanıldığı da kaydedilmiştir (Starovoytova, 2015, s. 156).

Rusçada etnonim temelli ön ek kullanılmadan türetilen fiillerin yazılı kaynaklarda başka bir kullanımının da mümkün olduğu kaydedilmiştir. Bu sefer fiillerin anlamsal alanında eylemci-nesne ilişkileri değil, eylemcinin yaptığı eylem bulunmaktadır. Dilsel boyutta bu eylemci odaklılığ filin geçişsiz kullanımı ile örtüşmektedir. Örneğin привычка французить (Fransızca konuşma alışkanlığı), русить во всём (her konuda Rus gibi davranmak) gibi öbeklerde fiilin anlamsal alanında başka bir boyutun ortaya çıktığı görülebilir (Starovoytova, 2015, s. 157).

19. yüzyılın sonundan itibaren etnonim bazında türetilen fiillerin anlamsal yapısında sonuç odaklılığından süreç odaklılığına geçiş olarak nitelenebilen 
bir süreç gözlemlenebilir (Starovoytova, 2017, s. 142). Bu süreç ön ekli modele göre türetilen fiilin уарısının -изова/-изирова son ekleri ile genişletilmesinde görülebilir. Örneğin мадьяризировать (Macarlaştırmak), германизировать (Almanlaştırmak), итальянизировать (İtalyanlaştırmak) biçimlerinde son eklerin oluşturduğu süreç odaklılı̆̆ı söz konusudur. Bu yapısal dönüşüm anlamsal boyutunun genişlemesini tetiklemiş̧ir. Ayrıca bu biçimler "bir eylemci/nesnenin başka nitelikleri kazanmasına sebep olmak" olarak açıklanabilen anlamı kodlamaya başlamıştır (Starovoytova, 2017, s. 142). Ettirgen ilişkileri yansıtan bu modelin yanı sıra "eylemci/nesnenin kendi kendine, dış etken olmadan başka nitelikleri kazanması" olarak düşünülen modelin de geliştiği anlaşılmaktadır. Eylemci odaklı bu yeni model, dilsel boyutta - $-c$ s son ekinin ortaya çıkmasıyla kendisini göstermiştir. Örneğin, германизировать-германизироваться (AlmanlaştırmakAlmanlaşmak $)^{26}$. Çağdaş Rusçada-изова/-изирова son ekleri ile türetilen fiillerin sosyo-politik gelişmeleri aktarmak için tercih edildiği görülebilir (Kaliuşçenko, 2016, s. 67). Örneğin русифицировать страницу поиска в интернете (arama motorunu Rusçalaştırmak), американизировать традиционную культуру (geleneksel kültürü Amerikanlaştırmak).

Yukarıda dile getirildiği gibi etnonim bazında türetilen sözcüksel birimler konuşmacının etnonimin kodladığı birey veya topluluk ile ilgili öznel değerlendirmelerini aktarabilmektedir. Rus dil dizgesinde bir birimdeki duygu yoğunluğu, kullanılan son eklere göre değerlendirilebilir. Duygu yoğunluğunun aktarılabildiği yapısal modellerden biri eylemci oluşturma modelidir. Dilsel boyutta isim kategorisinden isim türetilmekte, ancak türetilen isim, konuşmacının eylemciye yönelik olumlu ya da olumsuz tutumunu yansıtmaktadır. Rusçada konuşmacının öznel değerlendirmelerini aktarmak için çeşitli son ekler mevcuttur. Ancak bu son eklerin en büyük özelliği, bağlama göre konuşmacının farklı tutumlarını yans1tabilmektir. Etnonimlerde de bu özellik karşımıza çıkmaktadır. Örneğin çağdaş Rusçada - ишка son ekinin başlıca işlevinin, konuşmacının eylemciye yönelik sevecen tutumunu aktarmak olduğu söylenebilir (Krasilnikova, 2001, s. 19). Ay-

26 Rusçada başkasının yaptığı eylemin sonucunda bir sürecin geliştiğini ya da belli bir olgunun ortaya çıktığını göstermek için eylemcinin pasifleştirilmesi ve başka bir söz dizimsel modelin seçilmesi gerçekleşmektedir. Ayrıca Türkçedeki Almanlaşmak-Almanlaştırmak-Almanlaştırılmak birimlerindeki bilgileri Rusçada уарılandıracaksak германизироваться (онемечиться)-германизировать (онемечить)- его онемечили (sözcüğü sözcügüne: onu Almanlaştırdılar) türevleri ortaya çıkacaktır. 
rıca брат-братишка (kardeş-canım kardeşim), сын-сынишка (oğul-canım oğlum)) türevlerinde son ek sayesinde duygu yoğunluğunun değiştiği görülebilir. $\mathrm{Bu}$ örnekte -ишка son ekinin başka bir özelliği de karşımıza çıkmaktadır. Yukarıda Rusçadaki $-\kappa a$ son ekinin eril kategorisinden dişil kategorisinin türetilmesinde kullanıldığg gösterilmiştir (венгр-венгерка (Macar (erkek)-Macar (kadın), немец-немка (Alman (erkek)-Alman (kadın)). Сынишка (canım oğlum) ve братишка (canım kardeşim) örneğinde - $к a$ son ekinin dil dizgesinde eril kategorisinin türetilmesinde de kullanılabildiği anlaşılmaktadır. Ancak bu durumda türetilen yeni biçimin üslup açısından nötr olmadığını, konuşmacının eylemciye yönelik tutumunu gösterdiğini vurgulamak gerekmektedir. Bu modelin bazı etnonimlere uygulanabildiği görülür. Американец-америкашка (Amerikalı; konuşmacının bir Amerikalı'ya yönelik olumsuz, küçümseyici tutumunu aktaran biçim), еврей-еврейчик (Yahudi; konuşmacının bir Yahudi'yi önemsemediğine dair bilgi aktaran biçim) türevlerinin kök etnonimlerle eş anlamlı olmadığı anlaş1maktadır. Bunun yanı sıra bu türevlerdeki - аика/-чик son eklerinin pejoratif $\mathrm{f}^{27}$ anlamı iletmek için kullanıldığı da görülür. Pejoratif anlamlı türevlerde anlatım gücü yüksek olan $-a x /-y x /-y z$ gibi son ekler de kullanılmaktadır. Örneğin еврейеврюга (Yahudi; konuşmacının bir Yahudi'yi önemsemediğine dair bilgi aktaran biçim), итальянец-итальяха (İtalyan; konuşmacının bir İtalyan'1 önemsemediğine dair bilgi aktaran biçim) (Grişçenko, 2006, s. 183).

Araştırmacılar pejoratif anlamlı türevlerin her etnonim bazında değil, Rusçadaki belli başlı etnonimlerden oluşturulabildiğini dile getirmektedir (Berezoviç, 2002, s. 234). Bu etnonimlerin, Rusların tarih boyunca iletişim içinde bulunduğu millet ve toplulukların adları olduğu tahmin edilebilir. Ayrıca 20.yüzyılın ikinci yarısından itibaren ABD'nin dünya çapında hegemonyasını kurma çabalarının yankısı olarak Rusçada Amerikan etnonimi bazında pejoratif türevler ortaya çıkmıştır (американец-америкашка-америкос-американ (Amerikal1; konuşmacının bir Amerikalı'ya yönelik olumsuz, kü̧̈ümseyici tutumunu aktaran biçim)) (Pitina, 2016, s. 67). Rusların tarih boyunca Tatarlarla kurdukları çelişkili ilişkiler de татаришка (Tatar; konuşmacının bir Tatar'a yönelik olumsuz, küçümseyici tutumunu aktaran biçim)) türevine yansımıştır (Berezoviç, 2002, s. 233). 
Çağdaş Rusçadaki pejoratif anlamlı türevlerde son ekli modelin yanı sıra kısaltma modeli de görülebilir. Kısaltma modeline göre азербайджанец-азер (Azeri; konuşmacının bir Azeri'ye yönelik olumsuz, küçümseyici tutumunu aktaran biçim), дагестанец-даг (Dağıstanl1; konuşmacının bir Dağıstanlı'ya yönelik olumsuz, küçümseyici tutumunu aktaran biçim), вьетнамец-вьет (Viyetnamlı; konuşmacının bir Viyetnamlı'ya yönelik olumsuz, küçümseyici tutumunu aktaran biçim) gibi türevler ortaya çıkmıştır (Grişçenko, 2006, s. 183).

Etnonim kökenli pejoratif anlamlı türevlerin yapısında sözcük oyunları görülebilir. Sözcük oyunları anıştırma olguları aracıllğıyla yapılmaktadır (Kozan, 2014a, s. 138). Örneğin bazı Avrupa ülkelerinde eşcinsel (erkekler için Rusçada гей adlandırması) evliliklerin yasallaşması европеец $\rightarrow$ гейропеец (Avrupalı-eşcinsel Avrupalı) türevinin ortaya çıkmasına sebep olmuştur. Ukrayna'nın Avrupa Birliği'ne girme çabaları украинцы+Европа $\rightarrow$ укропейцы (Ukraynalılar+Avrup $\mathrm{a} \rightarrow$ Ukravrupalılar) türevi ile dile getirilmiştir (Dolya, 2016, s. 219).

\section{Etnonimlerin Yan Anlamları}

Yan anlam kültürdilbilim çerçevesinde ele alınan başlıca kavramlardan biridir (Kozan, 2014b, s. 6). Yan anlam ya da kültürel yan anlam, "kültürün dil göstergesinde yansıma biçimi”" (Teliya, 1996, s. 214), "nesnenin ya da olgunun aktarıldığ kavramın toplumda uyandırdığı değerler” (Apresyan, 1995, s. 159) olarak tanımlanmaktadır. Yan anlam; sözcük, deyim, atasözü, eğretileme, benzetme gibi dil dizgesinin farklı seviyelerinde kendini gösterebilmektedir. Araştırmacılar etnonimlerin, yan anlam bileşeni açısından zengin oluşumlar olduğunu vurgulamaktadır (Berezoviç, 2002, s. 236). Çağdaş Rusçada etnonimlerdeki yan anlamlar etnonim bazındaki türevlerde, etnonimler ile ilgili stereotiplerde (Taganova, 2014, s. 73), metaforlarda ve benzetmelerde kendini gösterebilmektedir.

Etnonimlerden türetilen fiil biçimleri yan anlam bileşini bulundurabilir. Örneğin цыганить (Çingene etnoniminden türetilen fiil) biçimindeki yan anlam "başkasını rahatsız edici bir şekilde dilenmek" olarak açıklanabilir (Berezoviç, 2002, s. 236; Starovoytova, 2015, s. 158). Bu fiilin başka yan anlamları da mevcuttur: "belli bir amaç olmadan dolaşmak, gezinmek", "biriyle alay et- 
mek" ve "ticarette sahtekârlık yapmak" biçiminde yan anlamları söz konusudur ${ }^{28}$. Rusçadaki еврей-жид ${ }^{29}$-жидовничать (Yahudi-lakap olarak kullanılan Yahudi etnonimi-Yahudi gibi davranmak) türevleri de yan anlamı içermektedir. Ayrıca жидовничать “cimri olmak" anlamında kullanılmaktadır (Dolya, 2016, s. 221).

Çağdaş Rusçadaki etnonimlerin kullanım sürecinde toplumda farklı sebeplerden oluşan stereotiplerin varlığ 1 görülebilir. Грек (Grek, Yunanlı) "içki, şarap tüketimi açısından sınır tanımayan kişi”, жид (Yahudi) “cimri biri”, еврейка (Yahudi kadın) "kızgın biri” biçimindeki kullanımlar söz konusudur (Berezoviç, 2002, s. 236). Турок (Türk) etnoniminin de yan anlamı mevcuttur. Türk etnonimi ile oluşan yan anlam "dil (Rusça) anlamamak" eylemi üzerinde "dil anlamayan biri” olarak açıklanabilir ${ }^{30}$. Zamanla anlam genişleme süreci gerçekleşmiş ve bu etnonimin yan anlamı "hiç bir şey anlamayan biri" olarak düşünülmeye başlanmıştır. Benzer bir durum yukarıda anlatılan немец (Alman) etnoniminde de görülebilir. Ayrıca Rusçayı anlamayan ve konuşamayan tüm yabancıların "dilsiz” (немой) olarak adlandırılması ve zamanla adlandırmanın sadece Almanlara (немцы) уönelik kullanılması söz konusudur. Rusça (Rusçayı konuşanlar da) açısından "dili anlamak/ anlamamak" kriterinin son derece önemli olduğu anlaşılmaktadır. Ayrıca bu kriterin deyimlerde sıkça ortaya çıktığı görülebilir. Örneğin Ты по-русски понимаешь? (sözcüğü sözcüğüne: Rusça anlıyor musun?), Я по-русски говорю? (sözcüğü sözcüğüne: Rusça mı konuşuyorum?) deyimleri konuşma dilinde sıkça kullanılan ve "sen beni/durumu vs. anlamıyorsun" anlamını taşıyan birimlerdir.

Etnonimlerle ilgili oluşan yan anlamlar metaforlarda ve benzetmelerde de görülebilir. Örneğin китайская грамота (Çiz yazısı) deyimindeki китайский (Çin (sıfat)) türevinin yan anlamı "anlaşılması zor, anlaşılmayan" olarak yorumlanabilir. Цыганский пот (Çingene teri) deyimi “üşümeye, titremeye eşlik eden terleme" anlamında kullanılmaktadır (Berezoviç, 2002, s. 236). Уйти поанглийски (İngiliz gibi ayrılmak) deyimi "vedalaşmadan çıkıp gitmek” anlamında kullanılmaktadır (Kozan, 2014a:143).

\footnotetext{
28 Yazılı kaynaklardaki örnekler için bkn. Rus Dili Derlemi sayfası: http://search1.ruscorpora.ru/search.xml?env=alpha\& mycorp $=\&$ mysent $=\&$ mysize $=\&$ mysentsize $=\&$ mydocsize $=\& \mathrm{dpp}=\&$ spp $=\&$ spd $=\&$ text $=$ lexform $\&$ mode $=$ main $\&$ sort $=$ gr ta gging\&lang $=$ ru\&nodia $=1 \&$ req $=\% \mathrm{~F} 6 \% \mathrm{FB} \% \mathrm{E} 3 \% \mathrm{E} 0 \% \mathrm{ED} \% \mathrm{E} 8 \% \mathrm{~F} 2 \% \mathrm{FC}$

29 Жид (Јида-Иуда-жид) sözcügü 20.yüzyıla kadar herhangi bir olumsuz yan anlamı olmadan "Yahudi” etnonimi olarak kullanılmıştır. Sovyet Döneminde bu sözcük pejoratif anlamlı bir birim niteliğinde kullanılmaya başlanmıştır (Krısin, 2015, s. 53).

30 Çağdaş Türkçede bu yan anlam "Fransız kalmak" deyiminde görülebilir.
} 


\section{Etnofolizmler}

Çağdaş Rusçada farklı milletleri, toplulukları adlandıran etnonimlerin yanı sıra bu oluşumları farklı belirtilerden yola çıkarak isimlendiren birimler mevcuttur. Bu birimlerin en büyük özelliği anlatım gücü yüksek olan birim niteliğinde olmaktır. Bu birimler "anlatım gücü yüksek olan etnonimler” (Yegorova, 2013, s. 44), “norm diş1 etnonimler” (Krisin, 2015, s. 47), “etnik lakaplar" (Gritsenko, 2006, s. 94), “etnofolizm” (Grişçenko, Nikolina, 2006, s.176) olarak adlandırılmaktadır. Araştırmacılar bir dildeki etnofolizmlerin ortaya çıkmasını “öteki” milletlere yönelik tahamülsüzlük, ön yargılar gibi psikolojik ve birtakım sosyo-kültürel etkenlere bağlamaktadırlar (Berezoviç, 2002, s. 237; Grişçenko, Nikolina, 2006, s. 176).

Çağdaş Rusçadaki etnofolizmler farklı adlandırma modellerine göre oluşmaktadır. Ayrıca adlandırma modelinde yerleşim yeri ön plana çıkabilir. Örneğin гора $\rightarrow$ горец (dağ $\rightarrow$ dağda yaşayan biri, dağlı) etnofolizminin, konuşma dilinde tüm Kafkasya kökenli insanlar için kulllanıldığı tespit edilmiştir (Berezoviç, 2002, s. 234). Москва $\rightarrow$ москаль (Moskova $\rightarrow$ Moskovalı) etnofolizmi Ukraynalılar tarafından kullanılmakta olup günümüzde sadece Moskovalılara yönelik değil, genel olarak Rusların adlandırılmasında görülebilir (Pitina, 2016, s. 66). Etnofolizm dış görünüş özelliklerine göre şekillenebilmektedir. Örneğin хохол (Ukraynalı) etnofolizminin ortaya çıkışı Moskova Knezliğinin güneyinde yaşayan erkeklerin saçını kesip bir tutam/perçem (хохол) bırakmaları ile ilişkilendirilmektedir (Zapryagayeva, Ş1şlannikova, 2015, s. 222). Bir milletin günlük hayatı ile ilgili özellikler de adlandırma modeli olarak kullanılabilir. Ayrıca макароны $\rightarrow$ макаронники (makarna $\rightarrow$ makarna yiyenler) etnofolizminin İtalyanlar, лягушка $\rightarrow$ лягушатники (kurbağa-kurbağa yiyenler) etnofolizminin ise Fransızlar için kullanıldığı tespit edilmiştir (Berezoviç, 2002, s. 234). Etnofolizm bir toplumda en çok kullanılan özel isimler bazında da oluşabilir. Ayrıca Rusçada Yahudilere yönelik абрам (Abraham), рабинович (Rabinoviç), сара (Sara) biçiminde özel isim niteliği kaybetmiş birimler kullanılmaktadır ${ }^{31}$. Orta Asya’dan gelenler için абдул (Abdul), мамед (Mehmet) birimleri söz konusudur. Ruslara

31 Bu dilsel süreç Rusçada апеллятивизация (apelativasyon; özel ismin cins isme dönüşmesi) olarak tanımlanmaktadır (Griş̧̧enko, 2006, s. 183). 
yönelik birçok dilde kullanılan etnofolizm, иван (İvan) biçimindedir. Etnofolizmler metonimi bazında da oluşabilmektedir. Örneğin африка (Afrika $\rightarrow$ Afrikalılar), азия (Asya $\rightarrow$ Asyalılar) birimleri özel isim niteliğini kaybedip cins isim olarak Afrika ya da Asya ülkelerinden gelenlere yönelik kullanılabilmektedir. Etnofolizmin arkasında ödünçlemeler bulunabilmektedir. Örneğin İngilizceden gelen ниггер (nigger (zenci)), чайна (İngilizce China (Çin)) etnofolizmleri sırasıyla Afrikalılara ve Çinlilere yönelik kullanılmaktadır.

\section{İkincil Adlandırmalar}

Çağdaş Rusçada etnonimler ikincil adlandırma sürecinde yer alabilmektedir. İkincil adlandırma, dil dizgesinde var olan adların yeni bir adlandırma işlevini üstlenmesi olarak tanımlanmaktadır (Teliya, 1977, s. 129). Etnonimlerin ikincil adlandırma aracı olarak kullanılması farklı açılardan ele alınabilen bir konudur. Bazı araştırmacılar bu konuyu eş seslilik açısından incelerken (Artzoyeva, Khalidov, 2017a) diğerleri ikincil adlandırma süreci çerçevesinde yaklaşmaktadır (Antipyeva, 2014, s. 145; Toçilo, 2017, s. 67). Etnonim durumunda ilk adlandırma (etnonim) ile ikinci adlandırma arasında metafor/metonimi bazında kurulan bir ilişki olduğu için ikincil adlandırma kavramının daha açıklayıcı olduğu varsayılabilir.

Çağdaş Rusçada etnonimler bitki adlandırılmasında kullanılabilmektedir. Örneğin гречка (karabuğday) adında грек-гречка (Grek (Yunanlı erkek)-Grek (Yunanlı kadın)) etnonimi görülebilir. Bu bitkinin Rusçada гречка (Yunanlı) olarak adlandırılması, bitkinin Ruslara Yunanlılarla birlikte gelmesi ile ilişkilendirilebilir (Vasmer, 1986:457). İlk başta гречка hem Yunanlı kadın hem bitki için kullanı-mış, ancak zamanla etnonimin yapısı değişmiştir. Ayrıca гречка etnonimi гречанка biçimini kazanmıştır (Artzoyeva, Khalidov, 2017a). Böylece de bir biçimin iki anlamlılığ sorunu giderilmiştir. Benzer bir durum etnonim bazında türetilen diğer bitki adlarında da görülebilir. Örneğin китайка (Çinli kadın) elma türü için kullanılan bir adlandırmadır. Etnonimin zamanla biçimini değiştirdiği anlaşılmaktadır: китайка (elma türü) $\rightarrow$ китаянка (Çinli kadın). "Etnonim $\rightarrow$ bitki adı" türevlerinde kimi zaman biçimsel değişiklikler ortaya çıkmamaktadır. Örneğin венгерка (Macar kadın) $\rightarrow$ венгерка (mürdüm eriği), американка (Amerikalı kadın) $\rightarrow$ американка 
(patates çeşidi), татарка (Tatar kadın) $\rightarrow$ татарка (bitki türü, Latincesi Allium fistulosum) çiftlerinde etnonimin ilk oluşan biçimiyle kullanıldığı anlaşılmaktadır.

Bitki adlarında etnonim türevleri de kullanılabilmektedir. Örneğin грецкий opex (ceviz) adlandırmasında греки $\rightarrow$ грецкий (Grekler $\rightarrow$ Grek (s1fat)) biçiminde isim kategorisinden sıfat kategorisinin türetildiği görülmektedir. Болгарский перец (kırmızı biber) adlandırmasında da isimden sıfat kategorisinin türetildiği anlaşılmaktadır (болгары $\rightarrow$ болгарский (Bulgarlar $\rightarrow$ Bulgar (sıfat)).

Çağdaş Rusçada etnonimler bitki adlandırmalarının yanı sıra nesne/ eşya/olgu adlandırmalarında da kullanılabilmektedir. Bu durumda da etnonim ikincil adlandırma biçimi ile aynı kalabilmekte ya da son ekler aracılı̆̆ıyla biçimi değiştirebilmektedir. Örneğin фин(н)ка $\rightarrow$ финка (Fin kadın $\rightarrow$ bıçak türü), голландка $\rightarrow$ голландка (Hollandalı kadın $\rightarrow$ soba türü), панамка $\rightarrow$ панамка (Panamalı kadın $\rightarrow$ hafif yaz şapkası), испанка $\rightarrow$ испанка ${ }^{32}$ (İspanyol kadın $\rightarrow$ İspanyol gribi), венгерка $\rightarrow$ венгерка (Macar kadın $\rightarrow$ dans türü; mont çeşidi), американка $\rightarrow$ американка (Amerikan kadın $\rightarrow$ bilardo türü) birimlerinde etnonimin ve ikincil adlandırma biçiminin aynı kaldığı görülebilir. Bazı durumlarda birimin iki anlamlılığını gidermek için Rusçanın dizgesindeki son ekler kullanılabilmektedir. Örneğin полька (Polonyalı kadın; dans türü) $\rightarrow$ полячка (Polonyalı kadın), турчанка (Türk kadın) - турка (cezve).

Bazı etnonimlerin ikincil adlandırma aracı olarak birkaç kez kullanıldığ1 anlaşılmaktadır. Örneğin американка (patates çeşidi; bilardo türü), венгерка (erik çeşidi; dans türü; mont türü) birimlerinde bu durum görülebilir. Bu anlamda çağdaş Rusçadaki etnonim bazında türetilen ikincil adlandırmaların çok anlaml1lığından söz edilebilir.

\section{Sonuç}

Çağdaş Rus dilinin dizgesinde etnonimler özel bir yere sahiptir. Bir taraftan dil dizgesinde bir birim olan etnonimler, Rusçadaki eylemci adlandırma modelinin gelişmişliği ile ilgili veri sunmaktadır. Çağdaş Rusçadaki etnonimlerin yapısında görülen çeşitli son eklerin, farklı dönemlerde işlevleriyle birlikte şekil-

32 Rusçada bu hastalığın adı direkt etnonimden değil, etnonim türevinden kısaltma yoluyla türetilmiştir: Аугıса испанский грипп $\rightarrow$ испанка (İspanyol grip $\rightarrow$ İspanyol (kısaltma)). 
lendiği ve farklı eylemci türlerinin adlandırılmasında kullanıldığı anlaşılmaktadır. Rusçadaki etnonim bazında türetilen birimlerin çözümlemesinin sonucunda dil dizgesindeki yapı-anlam bütünlüğü görülebilmektedir. Başka bir deyişle etnonim türevleri, gerçekliğin bir dil dizgesinde nasıl kodlandığını, anlamın yapıda nasıl şekillendiğini yansıtmaktadır. Diğer taraftan Rusçadaki etnonimler dil-kültür bütünlüğünü yansıtan birimler olarak karşımıza çıkmaktadır. Rusçadaki etnonimler, kültürel bileşenleri yoğun olan oluşumlardır. Etnonimlerin kullanıldığı metaforlar, etnonim bazında ortaya çıkan yan anlamlar ve stereotipler, birtakım sosyokültürel etkenlerin sonucu olup toplumun "ötekiler" olarak değerlendirilen diğer kavimlere, kültürlere yönelik tutumlarını yansıtmaktadır. Bir dile yansıyan "ötekileştirme" biçimleri imgebilim çerçevesinde ele alınması gereken bir konudur. $\mathrm{Bu}$ dilsel biçimlerin art ve eş zamanlı çözümlemesi, araştırmacılara bir kültürde başka bir toplum ile ilgili imgelerin nasıl oluştuğu ve geliştiğine dair geniş bilgi sunabilmektedir. Rusça etnonimlerdeki dil-kültür etkileşimi ikincil adlandırmalarda da gözlemlenebilir. Etnonimlerin tekil dişil biçimlerinin bitki ve nesnelerin adlandırılmasında kullanımı çağdaş Rusçadaki dilsel süreçlere dair bilgi vermektedir. Bunun yanı sıra etnonim bazında oluşan ikincil adlandırmalarda kültürler arasındaki etkileşimin nasıl gerçekleştiği görülebilmektedir.

Etnonimlerin eş zamanlı betimlenmesi sonucunda elde edilen veriler yabancı dil ve çeviri eğitimi açısından önem taşımaktadır. Gerek edebi metinlerde gerekse çağdaş medya söyleminde kullanılan etnonimlerin yan anlamları ile ilgili göndermelerin anlamlandırılması, etnonimlerin kullanıldı ğı metaforların algılanması, etnonimler ile ilgili takma adların kullanımındaki sözcük oyunlarının anlaşılması, dil öğretimi sürecinde etnonimlerin bir dil dizgesinde oluşturduğu yapısal ve anlamsal ağlarının çözümlemesine bağlıdır. Bu noktada etnonimlerin dilbilimsel çözümlemesinin, yabancı dil ve çeviri eğitimi sürecinde üzerinde durulması gereken bir konu olduğu söylenebilir. 


\section{Kaynakça}

Acar, K. (2014). Ortaçağ'dan Sovyet Devrimine Rusya. (İkinci Baskı). İstanbul: İletişim Yayınlar1.

Ahmetova, M. (2013). Yeşçe Raz o Suffikse -Çane (İstoriya Odnoy Polemiki). Russkiy Yazıkv Nauçnom Osveşçenii, 2(26), 65-90.

Antipyeva, İ. (2014). K Probleme Znaçeniya Etnonimiçeskih Edinits Vtoriçnoy Nominatsii. İzvestiya İGEA, 1 (93), 145-149.

Apresyan, Y. (1995). İzbrannıye Trudı. Tom 2. İntegralnoye Opisaniye Yazıka i Sistemnaya Leksikografiya. Moskova: Yazıki Russkoy Kulturı.

Artzoyeva, H. ve Khalidov, A. (2017a). Derivatı Jenskogo Roda V Etnonimikone Russkogo Yazıka. Vzlgyad Sovremennoy Molodejı Na Aktualnıye Problemı Gumanitarnogo Znaniya. Sbornik Trudov Mejregionalnoy Konferentsii, 198-203.

Artzoyeva, H. ve Khalidov, A. (2017b). İstoriya İzuçeniya Slovoobrazovaniya Russkih Etnonimov. Vzlgyad Sovremennoy Molodejı Na Aktualnıye Problemı Gumanitarnogo Znaniya. Sbornik Trudov Mejregionalnoy Konferentsii, 203-206.

Averçenko, V. (2018). Etnokulturnaya Obuslovlennost Semantiki Frazeologizmov S Etnonimami. Yazıkovaya Liçnost i Effektivnaya Kommunikatsıya v Politkulturnom Mire. Materialı III. Mejdunarodnoy Praktiçeskoy Konferentsii, 18-25.

Berezoviç, E. ve Gulik, D. (2002). Onomasiologiçeskiy Portret “Çeloveka Etniçeskogo": Printsıpı Postroyeniya İ İnterpretatsii. G.Neşçimenko (Ed.), Vstreçi Etniçeskih Kultur V Zerkale YazıkaV Sopostavitelnom Lingvokulturologiçeskom Aspekte içinde (s. 232-253). Moskova: Nauka.

Buyakov, A. (1994). Podgotovka Ofitserov V Vostoçnom İnstitute. İzvestiya Vostoçnogo İnstituta, (1), 64-71.

Diyanov, K. (2011). A. S. Lappo-Danilevskiy O Borbe Vostoçnikov S Zapadnikami. Vestnik Omskogo Universiteta. İstoriya, (3), 81-85.

Dolya, A. (2016). Etniçeskiye Prozvişça V Angliyskom İ Russkom Yazıkah: Motivatsıonnıy Aspekt. Praktiki İ İnterpretatsii, 1(1), 214-224.

Fuzuli, B. (2004). Oğuz Kavim Adının Etimolojisi. Karadeniz Araştırmaları, (3), 71-77.

Gorodetskaya, İ. ve Levaşov, E. (2003). Russkiye Nazvaniya Jiteley. Slovar-Spravoçnik. Moskova: Astrel-AST.

Grişçenko, A. ve Nikolina, N. (2006). Ekspressivnıye Etnonimı Kak Primetı Yazıka Vrajdı. İrina Vepreva (Ed.), Yazık Vrajdı I Soglasiya V Sotsiokulturnom Kontekste Sovremennosti içinde (s. 175-187). Yekaterinburg: Uralskiy Universitet. 
Gritsenko, İ. (2006). Konnotatsii Etnonima. Lingvokulturologiçeskiy Aspekt (Na Materiale Angliyskogo Yazıka). Kultura Narodov Priçernomorya, (86), 94-96.

Gruşevski, M. (1992). İstoriya Ukrain1-Rus1. T.1. Kiyiv: Naukova Dumka.

Hasanov, Z. (2009). "İskit” Etnonimin Okunuşu. İstanbul Üniversitesi Edebiyat Fakültesi Tarih Dergisi, 2(50), 1-10.

Kaliuşçenko, V. (2016). Glagolı, Motivirovannıye Etnonimami, V Nemetskom, Russkom İ Ukrainskom Yazıkah. Studia Germanika, Romanica et Comparatistica, (1), 64-69.

Kononov, A. (1949). Opıt Analiza Termina “Türk”, Sovetskaya Etnografiya, 1, 40-47.

Kovalev, G. (1991). Etnonimiya Slavyanskih Yazlkov. Nominatsiya I Slovoobrazovaniye. Voronej: Voronejskiy Universitet.

Kozan, O. (2014a). Rus Ve Türk Gazete Haber Başlı̆̆ı Dili. Kültürdilbilimsel Yaklaşım. Ankara: Gazi Kitabevi.

Kozan, O. (Ed.). (2014b). Kültürdilbilim. Temel Kavramlar Ve Sorunlar. Ankara: Gazi Kitabevi.

Krasilnikova, L. (2001). Uroki Po Russkomu Slovoobrazovaniyu Dlya İnostrannıh Uçaşçihsya. Moskova: Moskovskiy Universitet.

Krısin, L. (2015). Nenormativnıye Etnonimı. Problema Slovarnogo Opisaniya. Ekologiya Yazlka İ Kommunikativnaya Praktika, (1), 46-56.

Misenko, O. (2005). K Voprosu O Morfologiçeskoy Strukture Etnonima "Russkiy". Vestnik $O G P U, 2$ (40), 52-57.

Nadirbayeva, K. (2016). “Manas” Destanındaki Etnonimler. Uluslararası Sosyal Bilimler Dergisi, Özel Sayı 1, 7-16.

Nikonov, V. (1970). Etnonimı. Moskova: Nauka.

Pantyuhova, P. (2013). Frazeologizmı-Etnonimı V Sopostavitelnom Analize Yazıkovogo Koda İspanskoy İ Angliyskoy Lingvokultur. Filologiçeskiye Nauki. Voprosı Teorii İ Praktiki, 4-1(22), 139-142.

Pitina, S. (2016). Angliyskiye İ Russkiye Etnonimı V Sopostavitelnom Aspekte. Vestnik Çelyabinskogo Gosudarstvennogo Universiteta, 12(394), 65-70.

Plis, İ. (2018). Tipologiçeskaya Klassifikatsiya Etnonimov Russkogo Yazıka. Yazıkovaya Liçnost i Effektivnaya Kommunikatslya v Politkulturnom Mire. Materialı IV. Mejdunarodnoy Praktiçeskoy Konferentsii, 144-148.

Podolskaya, N. (1978). Slovar Russkoy Onomastiçeskoy Terminologii. Moskova: Nauka.

Popova, E. ve Al-Hamdani, S. (2018). Datskiye, Prusskiye, Frantsuzkiye Nemtsı. Ustarevşıy Alloetnonim "Nemtsı” V Russkoy Lingvokulture. Vtoriye Şçeylinskiye Çteniya. Materialı Vserosiyskoy Nauçnoy Konferentsii, 95-106. 
Russkaya Grammatika (1980), T.1. Moskova: Nauka.

Savitski, V. (2009). Nove Tlumaçennya Toponimu “Ukraina”. Storinkı İstorii, (28), 3-9.

Skorobogatova, T. (2006). Etnoidiomatika V Sovremennom Frantsuzskom Yazıke. Yazık, Tekst, Diskurs, (4), 192-199.

Smirnov, İ. (2012). Ekspressivnıye Etnonimı v Sovremennom Nemetskom Yazıke Avstrii. Vestnik Leningradskogo Gosudarstvennogo Universiteta İmeni A.S. Puşkina, 1(2), 204-213.

Starovoytova, O. (2015). Ob Odnoy Glagolnoy Slovoobrazovatelnoy Modeli V Sovremennom Russkom Yazıke: Dinamiçeskiy Aspekt. Vestnik SpbGU, 9(1), 154-161.

Starovoytova, O. (2017). Opisaniye Mejetniçeskih Kontaktov V Ruskkom Yazıke XIX Veka Skvoz Prizmu Otglagolnoy Leksiki. Aktualnıye Problemı Filologii I Pedagogiçeskoy Lingvistiki, (3), 141-151.

Subtelnı, O. (1993). Ukraina: Istoriya. Kiyiv: Libid.

Şahin, İ. (2018). Adbilim (3.bs.). Ankara: Pegem.

Şahmatov, A. (1940). Povest Vremennıh Let i Yeye İstoçniki. Trudı Otdela Drevnerusskoy Literaturl, 4, 9-150.

Şulga, M. (2014). Vostiçniki i Yevraziytsı: Dve Versii Odnoy Geostrategii? Gumanitarnıye İssledovaniya V Vostoçnoy Sibiri İ Na Dalnem Vostoke, (2), 87-97.

Taganova, T. (2014). Etnostereotip. Lingvistiçeskiy İ Leksikografiçeskiy Aspektı. Vestnik İvanovskogo Gosudarstvennogo Universiteta. Filologiya, (1), 72-77.

Teliya, V. (1977). Vtoriçnaya Nominatsiya İ Ee Vidı. Boris Serebrennikov (Ed.), Yazıkovaya Nominatsiya. Vidı Naimenovaniy içinde (s. 129-22). Moskova: Nauka.

Teliya, V. (1996). Russkaya Frazeologiya. Semantiçeskiy, Pragmatiçeskiy i Lingvokulturologiçeskiy Aspekt. Moskova: Yazıki Russkoy Kulturı.

Toçilo, N. (2017). Upotrebleniye Etnonima "Yaponets" Vo Vtoriçnoy Nominatsii. Sovremennıye Tehnologii V Nauke İ Obrazovanii: Problemı, Dostijeniya, Perspektivl. Materialı II Mejdunarodnoy Nauçno-Praktiçeskoy Konferentsii, 67-72.

Tsebrovskaya, T. (2017). Perevod Derogativno Markirovannıh Etnonimov, Motivirovannıh Etnorasovımi Stereotipami. Vestnik Çerepovetskogo Gosudarstvennogo Universiteta, (5), 115-120.

Vasmer, M. (1986). Etimologiçeskiy Slovar Russkogo Yazıka. T.1. Moskova: Progress.

Vasmer, M. (1987). Etimologiçeskiy Slovar Russkogo Yazıka. T.4. Moskova: Progress.

Yartseva, V. (1998). Bolşoy Entsıklopediçeskiy Slovar. Yazıkoznaniye. Moskova: Bolşaya Russkaya Entsıklopediya.

Yegorova, V. (2013). Emotivnaya Leksika V Lingvistike. İzvestiya YZGU. Lingvistika İ Pedagogika, (2), 44-49. 
Yeremeyev, D. (1970). K Semantike Tyurkskoy Etnonimii. Vladimir Nikonov (Ed.), Etnonimı içinde (s. 133-143). Moskova: Nauka.

Zapryagayeva, M. ve Şışlyannikova, A. (2015). Sposobı Sozdaniya Peyorativnoy Otsenki v Yazıke "Vrajdı" (Na Materiale Novoy Leksiki Mass-Media). Professionalnaya Reçevaya Kommunikatsiya İ Mass-Media. IV Mejdunarodno-praktiçeskiySeminar, 219-223.

Znaçenok, V. ve Plis, İ. (2018). Etnonimı V Belorusskih İ Angliyskih Frazeologizmah. Yazlkovaya Liçnost i Effektivnaya Kommunikatslya v Politkulturnom Mire. Materialı III. Mejdunarodnoy Praktiçeskoy Konferentsii, 145-152. 